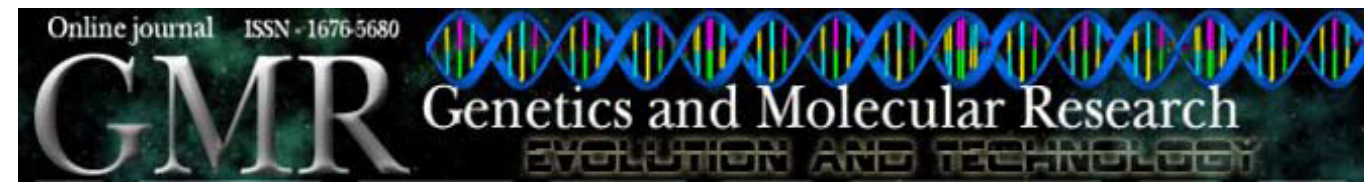

\title{
Genetic polymorphism, molecular characterization and relatedness of Macrobrachium species (Palaemonidae) based on RAPD-PCR
}

\author{
A.L. Guerra ${ }^{1}$, A.V.B. Lima ${ }^{1}$, F.G. Taddei ${ }^{2}$ and L. Castiglioni ${ }^{2}$ \\ ${ }^{1}$ Departamento de Biologia, Universidade Estadual Paulista, \\ São José do Rio Preto, SP, Brasil \\ ${ }^{2}$ Departamento de Biologia, Centro Universitário de Rio Preto, \\ São José do Rio Preto, SP, Brasil \\ Corresponding author: L. Castiglioni \\ E-mail: clilian@terra.com.br
}

Genet. Mol. Res. 9 (4): 2317-2327 (2010)

Received July 26, 2010

Accepted September 17, 2010

Published November 30, 2010

DOI 10.4238/vol9-4gmr935

ABSTRACT. The prawn genus Macrobrachium belongs to the family Palaemonidae. Its species are widely distributed in lakes, reservoirs, floodplains, and rivers in tropical and subtropical regions of South America. Globally, the genus Macrobrachium includes nearly 210 known species, many of which have economic and ecological importance. We analyzed three species of this genus (M. jelskii, M. amazonicum and M. brasiliense) using RAPD-PCR to assess their genetic variability, genetic structure and the phylogenetic relationship between them and to look for molecular markers that enable separation of $M$. jelskii and $M$. amazonicum, which are closely related syntopic species. Ten different random decamer primers were used for DNA amplification, yielding 182 fragments. Three of these fragments were monomorphic and exclusive to $M$. amazonicum or M. jelskii and can be used as specific molecular markers to identify and separate these two species. Similarity indices and a phylogenetic tree showed that $M$. amazonicum and $M$. jelskii are closest to each other, while $M$. brasiliense was the most differentiated species among them; this may be attributed to the different habitat 
conditions to which these species have been submitted. This information will be useful for further studies on these important crustacean species.

Key words: RAPD-PCR; Macrobrachium; Polymorphism; Prawn; Phylogenetic relathionship; Crustacean

\section{INTRODUCTION}

The genus Macrobrachium (Bate, 1868) includes several species of prawns widely distributed in lakes, reservoirs, floodplains, and rivers in tropical and subtropical regions of South America, including all the main river basins (Orinoco, Amazon, Araguaia, Tocantins, São Francisco, Paraná, and Paraguai River basins), as well as the smaller rivers of the South Atlantic Basin in the northern, northeastern, and eastern coasts of Brazil (Melo, 2003; Maciel and Valenti, 2009). Currently, there are nearly 210 species known worldwide, of which 45 are registered in the Americas, including about 18 in Brazil (Melo, 2003).

The term prawn has a very broad meaning. It is used to characterize species whose entire life cycle is restricted to freshwater, as well as those that need brackish water at the beginning of their development and later freshwater after metamorphosis (Sampaio et al., 2007). They are decapod crustaceans belonging to the Suborder Pleocyemata, Infraorder Caridea, Superfamily Palaemonoidea, and Family Palaemonidae. Although they are also called prawns, like saltwater shrimp, they are considered to be closer to lobsters, since they share many similarities mainly regarding their reproductive habits, because the female prawns, similar to lobsters, keep their eggs in the abdomen until spawning time (Valenti, 1993; Martin and Davis, 2001).

Most of the prawn species of economic importance belong to the genus Macrobrachium. They are widely exploited by artisan fisheries and used as protein sources by humans and other animals, and in addition, these prawns show a high potential for aquaculture. In recent years, intense research efforts have been directed toward developing the technology for commercial culture of this species (Valenti, 1993; Moraes-Valenti and Valenti, 2007, 2010).

Besides economic factors, the Macrobrachium species have been shown to play important ecological roles (Magalhães, 2000; Magalhães et al., 2005). However, their biological characteristics and genetic structure are poorly understood.

According to Magalhães (2000), several species that occupy different habitats, including those within the genus Macrobrachium, have shown interesting adaptive particularities in their morphological and physiological aspects and behavioral patterns that could be the object of many studies. These studies are important since in several basins drastic environmental changes have occurred due to the presence of exotic species, pollution and the deterioration of aquatic ecosystems caused by human occupation.

As described by Magalhães et al. (2005), M. amazonicum and M. jelskii have similar geographic distribution throughout South America (from Venezuela to northern Brazil), and also the basins of the Orinoco, Amazonas, and lower Paraná, and the northeast and southeast regions of Brazil, including the State of São Paulo. Particularly in this state, the introduction of both species could have been caused by humans who have interfered by cultivating them for commercial purposes (live bait for a practice known as "fish-pay") or by their accidental escape from the fish breeding stations of CESP (Companhia Energética de São Paulo), probably in the early 1970 s. 
Also according to Magalhães et al. (2005), there are several difficulties in taxonomic classification of some species of Macrobrachium that are based only on morphological characteristics so that even the literature regarding this problem is of poor value. Such difficulties are most evident between M. amazonicum and M. jelskii, which have many morphological similarities that hinder their identification, and this may even be increased because they are syntopic species.

In the present study, we contribute to the biological knowledge of three Macrobrachium species: M. amazonicum, M. jelskii and M. brasiliense, using RAPD-PCR (random amplified polymorphic DNA by polymerase chain reaction) markers to study their genetic polymorphism, to obtain molecular markers to enable the identification of mainly M. jelskii and M. amazonicum, which are closely related and syntopic species, and also to assess the phylogenetic relationship between them. These species are very interesting because they were recently introduced in our river basins, and currently, they are widely distributed in our region.

RAPD-PCR was chosen because it is considered to be a means of rapidly detecting genetic polymorphisms. Among the many molecular methods currently available for genetic studies, it appears particularly suitable for analysis of any species, revealing a high degree of polymorphism in many cases (Williams et al., 1990; Garcia et al., 1998; Castiglioni and de Campos Bicudo, 2005; Roratto et al., 2008; Cesniene et al., 2010; Nath et al., 2010). The method uses PCR with a single short oligonucleotide primer that randomly amplifies short fragments of genomic DNA, separated by size, with agarose gel electrophoresis. Because the RAPD technique explores many loci, it is considered to be appropriate for analysis of genetic distance and phylogenetic relationships.

\section{MATERIAL AND METHODS}

\section{Sample sources and DNA extraction}

DNA was extracted from Macrobrachium species collected at the following localities: M. amazonicum (Ma) and M. jelskii (Mj) were collected from the Barra Mansa

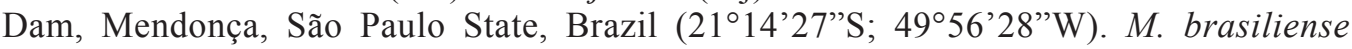
$(\mathrm{Mb})$ samples were obtained from the Talhadinho Stream, Talhados, São Paulo State, Brazil $\left(20^{\circ} 47^{\prime} 07^{\prime \prime} \mathrm{S} ; 4^{\circ} 20^{\prime} 35^{\prime \prime} \mathrm{W}\right)$. The outgroup was Potimirin glabra (Pg), collected in Ubatuba, São Paulo State, Brazil (2326"13”S; $\left.45^{\circ} 04^{\prime} 08^{\prime \prime W}\right)$. DNA was individually extracted from 42 adults of each Macrobrachium species studied and 12 individuals of $P$. glabra, used as an outgroup.

Genomic DNA was prepared as described by Dellaporta et al. (1983), with modifications adapted by Castiglioni and de Campos Bicudo (2005). Approximately $1 \mathrm{~g}$ muscle tissue was homogenized in microtubes with $160 \mu \mathrm{L}$ cold solution I (10 mM Tris, $60 \mathrm{mM} \mathrm{NaCl}, 5 \%$ sucrose, $10 \mathrm{mM}$ EDTA, pH 7.8). After adding $200 \mu \mathrm{L}$ solution II (300 mM Tris, $1.25 \%$ SDS, $5 \%$ sucrose, $10 \mathrm{mM}$ EDTA, $\mathrm{pH} 8.0$ ), the homogenate was mixed and the tube placed in a water bath at $65^{\circ} \mathrm{C}$ for $30 \mathrm{~min}$. Next, $60 \mu \mathrm{L} 3 \mathrm{M}$ sodium acetate was added and the tube was cooled at $-20^{\circ} \mathrm{C}$ for $20 \mathrm{~min}$. After centrifugation twice for $15 \mathrm{~min}$ at $13,000 \mathrm{rpm}$, an equal volume of isopropanol was added to the recovered aqueous phase, and the sample was maintained at room temperature for $5 \mathrm{~min}$. After another centrifugation for $10 \mathrm{~min}$ at 13,000 rpm, the pellet was rinsed with $70 \%$ ethanol, dried at room temperature and resuspended in $100 \mu \mathrm{L}$ TE buffer (10 mM Tris, 1 mM EDTA, pH 8.0). 


\section{Primers and amplification reaction}

DNA was amplified using 10 random decamer primers (selected among 20 previously tested for the quality of bands produced) whose base sequences are in Table 1 . The primers used were Operon-RAPD ${ }^{\circledR} 10$ mer obtained from Operon Technologies (Alameda, CA, USA).

\begin{tabular}{ll} 
Table 1. Nucleotide sequences of the 10 RAPD primers used in the present study. \\
\hline Primer & Nucleotide sequence $5^{\prime}-3^{\prime}$ \\
\hline 02 & GTT GCG TTC C \\
08 & GTG ACG TAG G \\
09 & TAC CGA AGC C \\
10 & GTG ATC GCA G \\
11 & CAA TCG CCG T \\
13 & CAG CAC CCA C \\
14 & TCT GTG CTG G \\
15 & TTC CGA ACC C \\
20 & AGG TGA CCG T \\
\hline
\end{tabular}

The amplification reaction was performed in a $25-\mu \mathrm{L}$ volume containing $2.5 \mathrm{U}$ Taq DNA polymerase (Biotools), $20 \mathrm{mM}$ Taq DNA polymerase buffer, $3 \mathrm{mM} \mathrm{MgCl}$, $0.2 \mathrm{mM}$ of each dNTP, $0.2 \mu \mathrm{M}$ primer, $25 \mathrm{ng}$ genomic DNA and sterile MilliQ water. Amplifications were performed using an Eppendorf Thermocycler. The reaction profile was: $94^{\circ} \mathrm{C}$ for $3 \mathrm{~min} ; 45$ cycles for $30 \mathrm{~s}$ at $94^{\circ} \mathrm{C}, 1 \mathrm{~min}$ at $35^{\circ} \mathrm{C}$ and $2 \mathrm{~min}$ at $72^{\circ} \mathrm{C}$, and 5 min at $72^{\circ} \mathrm{C}$. The amplification was submitted to electrophoresis on a $1.5 \%$ agarose gel at $70 \mathrm{~V}$ for $2 \mathrm{~h}$, stained with ethidium bromide and visualized under UV light. The DNA marker used on the gel to determine fragment sizes was 1-kb DNA ladder (GE Healthcare Life Science do Brasil, Ltda.). The size of each fragment was estimated in bp, by finding the distance between its location and the location of the band closest to the DNA ladder.

We took precautions in relation to the factors that can affect reproducibility of RAPD profiles by keeping the experimental conditions constant and by avoiding contaminations. Besides, only the bands with frequencies of at least $10 \%$ were considered, in order to avoid bands possibly resulting from non-specific amplification (Castro and Madi-Ravazzi, 2000; Castiglioni and de Campos Bicudo, 2005).

We also performed experiments to verify the polymorphism pattern generated by each of the 10 primers used in this study. Each individual that showed all the bands generated by each primer was selected, and DNA was amplified again by PCR, under the same previously standardized conditions. After electrophoresis, also conducted under the same conditions described above, the amplified bands were analyzed and the results compared with the previous analysis in order to establish and confirm the genetic profile generated for each species by each primer.

\section{Data analysis}

For detecting genetic relatedness between species, a data matrix for all primers was produced, with each individual being represented as a vector of 1 and 0 (for the presence or absence of a fragment, respectively). In the phylogenetic analysis, the PAUP (Phylogenetic Analysis Using Parsimony 4.0, beta version) program developed by Swofford (2000) 
was used. This analysis was performed using the neighbor-joining algorithm and bootstrap proportions (1000 replicates) that determine the confidence level in each node of the phylogenetic trees. The trees were rooted by adding $P$. glabra as an outgroup. The genetic similarity was computed on the basis of shared bands, as described by Nei and Li (1979). The similarity indices were calculated separately for each primer and for the complete set of primers using the mean similarity indices.

\section{RESULTS}

The results obtained herein refer to the amplification product produced by using 10 random decamer primers in three shrimp species analyzed in this study, plus the external group. The polymorphic fragments generated by the RAPD-PCR technique were confirmed from experiments carried out to obtain a genetic profile generated by each primer, in each species.

A total of 182 fragments were obtained, with molecular weights varying from 2.40 to $0.30 \mathrm{~kb}$. As shown in Table 2, the amplification product resulted in totals of 68, 65, 74, and 71 fragments in species $\mathrm{Mj}, \mathrm{Ma}, \mathrm{Mb}$, and $\mathrm{Pg}$, respectively. Primer 9 was the most polymorphic, producing a total of 25 different bands, while primer 18 was the least polymorphic, producing a total of 11 different bands.

\begin{tabular}{|c|c|c|c|c|c|}
\hline \multirow[t]{2}{*}{ Primer } & \multirow[t]{2}{*}{ Total number of bands } & \multicolumn{4}{|c|}{ Species } \\
\hline & & $\mathrm{Mj}$ & $\mathrm{Ma}$ & $\mathrm{Mb}$ & $\mathrm{Pg}$ \\
\hline 02 & 23 & 6 & 10 & 9 & 12 \\
\hline 08 & 22 & 5 & $7(1)$ & 7 & 10 \\
\hline 09 & 25 & 8 & 6 & 8 & 7 \\
\hline 10 & 14 & 8 & $6(1)$ & 6 & 3 \\
\hline 11 & 21 & $9(1)$ & 10 & 8 & 12 \\
\hline 13 & 15 & 8 & 9 & 9 & 6 \\
\hline 14 & 15 & 8 & 5 & 5 & 3 \\
\hline 15 & 19 & 7 & 6 & 7 & 7 \\
\hline 18 & 11 & 3 & 4 & 9 & 2 \\
\hline 20 & 17 & 6 & 2 & 6 & 9 \\
\hline Total & 182 & 68 & 65 & 74 & 71 \\
\hline
\end{tabular}

In parentheses is the number of monomorphic and exclusive bands produced by individual primers in $\mathrm{Mj}$ and $\mathrm{Ma}$. $\mathrm{Mj}=$ M. jelskii $; \mathrm{Ma}=$ M. amazonicum $; \mathrm{Mb}=$ M. brasiliense $; \mathrm{Pg}=$ Potimirin glabra .

Of all the fragments obtained, three can be utilized as specific markers for $\mathrm{Mj}$ and $\mathrm{Ma}$, since they were monomorphic (visualized in $100 \%$ of the individuals analyzed), and exclusive to one or the other species: a fragment of $0.60 \mathrm{~kb}$ generated by primer 08 , exclusive to Ma; a fragment of $1.50 \mathrm{~kb}$, generated by primer 10 , also exclusive to this species, and a $0.60-\mathrm{kb}$ fragment, the amplification product of primer 11, exclusive to Mj (Table 2; Figure 1).

For the phylogenetic analysis, based on data obtained in the present study, evaluated discretely (presence/absence), the bootstrap method was utilized with a neighbor-joining search (PAUP 4.0 program). The analyses were carried out using 182 fragments obtained by the RAPDPCR technique, producing the phylogenetic tree shown in Figure 2. This figure reveals that $\mathrm{Mb}$ constitutes a more peripheral branch, therefore being the most differentiated of the three species in the study, jointly with the outgroup Pg. Mj and Ma were found to be phylogenetically closer, comprising sister branches, with a highly significant dichotomy position (84\%). 


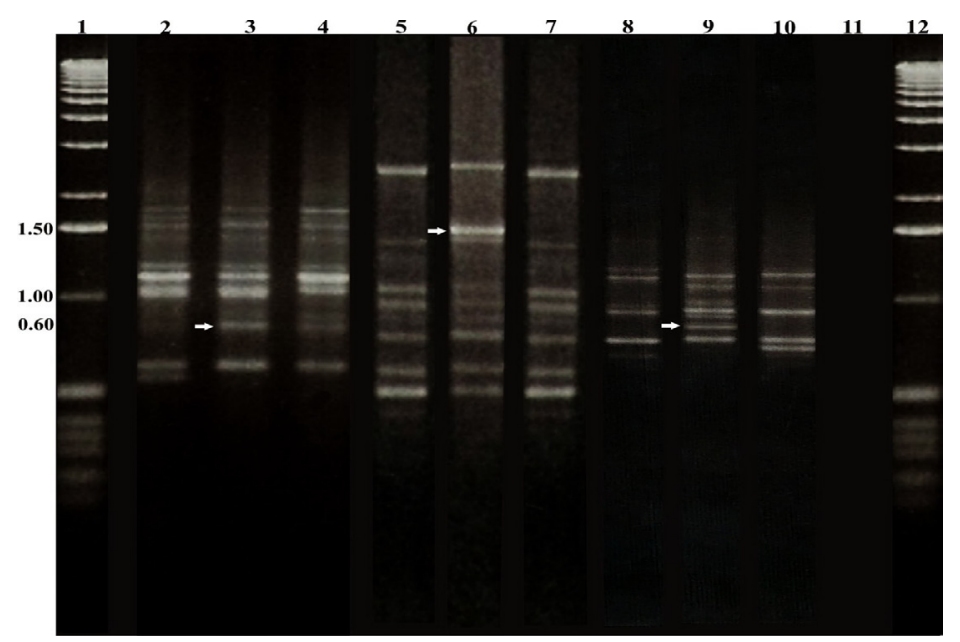

Figure 1. Agarose gel (1.5\%) showing the different banding pattern observed among Macrobrachium species using the primer 08 (lanes 2-4), primer 10 (lanes 5-7) and primer 11 (lanes 8-10). Lanes 1 and 12: Molecular weight markers (1-kb DNA ladder). Mj: lanes: 2, 5 and 9; Ma: lanes 3, 6 and 8; Mb: lanes 4, 7 and 10. Lane 11: Negative control (without DNA). The white arrows indicate the monomorphic bands, exclusive to $\mathrm{Ma}$ or $\mathrm{Mj} . \mathrm{Mj}=M$. jelskii; $\mathrm{Ma}=$ M. amazonicum $; \mathrm{Mb}=$ M. brasiliense.

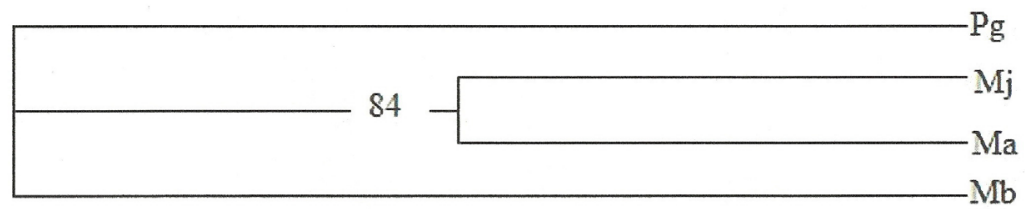

Figure 2. Phylogenetic tree produced by the PAUP 4.0 program for fragments obtained with all primers together. $\mathrm{Pg}=$ Potimirin glabra (as the outgroup); $\mathrm{Mj}=$ Macrobrachium jelskii $; \mathrm{Ma}=$ M. amazonicum $; \mathrm{Mb}=$ M. brasiliense .

Table 3 displays mean similarity indices, calculated for the species analyzed in the present study, with two-by-two comparison, also including the external group. The calculation of the indices took into account the number of bands shared between any two species and the total number of bands present in each species compared, carried out for each primer. Afterward, the mean values were calculated, as specified in this table.

From the analysis of these data, we can observe a greater similarity between $\mathrm{Mj}$ and $\mathrm{Ma}$ (0.4903), and a lesser one between $\mathrm{Mj}$ and $\mathrm{Mb}(0.4363)$. In the same manner, the comparison between $\mathrm{Ma}$ and $\mathrm{Mb}$ showed a lower similarity index (0.4304) than that obtained with the $\mathrm{Mj}-\mathrm{Mb}$ comparison. These values indicate the existence of a greater genetic proximity between $\mathrm{Mj}$ and $\mathrm{Ma}$.

\begin{tabular}{|c|c|c|c|c|}
\hline & $\mathrm{Mj}$ & $\mathrm{Ma}$ & $\mathrm{Mb}$ & $\mathrm{Pg}$ \\
\hline $\mathrm{Mj}$ & 1 & & & \\
\hline Ma & 0.4903 & 1 & & \\
\hline $\mathrm{Mb}$ & 0.4363 & 0.4304 & 1 & \\
\hline $\mathrm{Pg}$ & 0.1977 & 0.1988 & 0.1907 & 1 \\
\hline
\end{tabular}

$\mathrm{Mj}=$ M. jelskii $; \mathrm{Ma}=$ M. amazonicum $; \mathrm{Mb}=$ M. brasiliense $; \mathrm{Pg}=$ Potimirin glabra . 


\section{DISCUSSION}

Understanding the evolution of species requires a description of intra- and interspecific variability and the ability to distinguish the potential causes of the observed distribution of variation (Cognato et al., 1995).

Thus, one of the current challenges in biology is to organize the large amount of molecular data available so as to elucidate how the organisms are related and how they have been derived from the evolutionary process. Among the methodologies available, the RAPD-PCR technique has been amply utilized in different organisms, due to its aforementioned characteristics, with results considered important for this objective (Garcia et al., 1998; Iqbal et al., 2007; Camargo Jr. et al., 2007; Roratto et al., 2008; Guerra Jr. et al., 2010).

In the present study, the RAPD technique was employed to study the genetic variability in three shrimp species of the genus Macrobrachium, utilizing P. glabra as the outgroup, and 10 random decamer primers previously selected from a kit containing 20 primers. As already mentioned, only the bands with a frequency of at least $10 \%$ were considered, in an attempt to avoid including bands with non-specific amplification (Castro and Madi-Ravazzi, 2000; Castiglioni and de Campos Bicudo, 2005). In this manner, 182 fragments were obtained from the species analyzed, varying from 2.40 to $0.30 \mathrm{~kb}$, with $\mathrm{Mb}$ being the most polymorphic (74 fragments) followed by Mj (68 fragments) and Ma (65 fragments). In the Pg external group, 71 fragments were observed by RAPD-PCR.

Our interest in analyzing the genetic variability of these species arises not only from their economic and ecological importance, as emphasized in previous studies, but also from the paucity of studies on their biology, from the syntopic and taxonomic difficulties in their identification, and from the fact that $\mathrm{Mj}$ and Ma have been introduced into our region (Kensley and Walker, 1982; Magnusson et al., 1987).

Currently, the identification of these species is based on the observation of a few morphological aspects based on the terminus of the telson (Melo, 2003). Nevertheless, such characteristics are difficult to visualize due to the small size of individuals and to the anatomical structures considered. Even so, this situation is aggravated by the fact that these are syntopic species, where these characteristics are even more diminutive in their young immature forms. These factors, taken together, have led to some hypotheses that they are only a single species, metapopulations or, even, interspecific hybrids (Taddei FG, personal communication). However, as already noted, literature data that address and clarify these doubts, unfortunately, do not yet exist.

One of the applications of the RAPD-PCR technique is obtaining specific molecular markers capable of diagnosing populations and species, for taxonomic reasons. As important characteristics, such markers must be exclusive to the species in question and preferentially monomorphic, that is, found with $100 \%$ frequency among the individuals analyzed (Castiglioni and de Campos Bicudo, 2005; Rampelotti et al., 2008; Rahman et al., 2009).

One of the objectives of the present study, as already stated, was to obtain good RAPD-PCR markers capable of identifying the species studied, principally $\mathrm{Mj}$ and $\mathrm{Ma}$, which are syntopic and morphologically very similar. Thus, two bands were found exclusive to Ma, generated by the primers 08 and 10 , and one band exclusive to $\mathrm{Mj}$, generated by primer 11, all monomorphic. According to the characteristics shown by these bands, they may be considered good markers able to diagnose $\mathrm{Mj}$ and $\mathrm{Ma}$, syntopic species that show taxonomic identification difficulties based only on morphological characteristics, due to the high level of morpho- 
logical similarity between these two species. Furthermore, according to studies conducted by Taddei et al. (2006) and Sampaio et al. (2007), there is ample diversity in size among the individuals of the same population and also among different populations, depending on environmental variations, which can hinder their identification even more.

The RAPD-PCR technique has been successfully utilized in studies with taxonomic aims. Wilkerson et al. (1995) utilized the RAPD technique to differentiate four cryptic species of the complex Anopheles (Nyssorhymchus) albitarsis, distributed in Brazil, Paraguay and Argentina. According to these authors, the correct identification of mosquitoes belonging to the genus Anopheles is an important prerequisite for epidemiological studies involving the planning and monitoring of programs for control and eradication.

Castro and Madi-Ravazzi (2000) tested the taxonomic potential of the RAPD technique in species of Drosophila belonging to the group buzzatii, since there are intriguing aspects related to the speciation process in this group. Several lineages of D. buzzatii, D. seriema, D. koepferae, and $D$. serido were analyzed. The polymorphism detected permitted recognition of different lineages and species and confirmed the existent phylogenetic relationship between them.

The fact that the RAPD-PCR technique is capable of simultaneously exploring many gene loci highlights the need for studies on genetic distance, phylogenetic relationships and genetic identity among populations and species, to obtain data that enable the characterization of the origin and dispersion of organisms and detection of individuals and populations genetically resistant to diverse chemicals including insecticides (Garcia et al., 1998; Castiglioni and de Campos Bicudo, 2005; Cesniene et al., 2010).

In another study, Castiglioni and de Campos Bicudo (2005) genetically characterized, by RAPD-PCR, populations of Haematobia irritans (horn fly), an important bovine parasite. Four Brazilian populations were analyzed (Rio Branco, AC; Cassilândia, MS; Turiúba, and São José do Rio Preto, SP, Brazil) as well as an additional one from the United States (Kerrville, TX, USA). In addition to genetically characterizing these populations by the presence of specific fragments, it was possible, based on the data obtained, to evaluate the phylogenetic relationships between them, thus confirming the advantages of using the RAPD-PCR technique as a molecular tool in genetic analysis of populations.

In the present study, the results obtained with RAPD were also utilized to infer genetic similarity and notable phylogenetic relationships between the species analyzed. The mean similarity indices were calculated according to Nei and Li (1979) and confirmed the same genetic proximity as shown in the phylogenetic tree.

The phylogenetic tree, obtained via parsimony utilizing the neighbor-joining algorithm and applying the bootstrap method (Swofford, 2000), showed results of good reliability based on the attainment of a highly significant dichotomy (84\%). Analysis of this tree, together with the calculations of the mean similarity indices, reveals that $\mathrm{Mb}$ constituted the most peripheral branch, therefore being the most differentiated of the three species in the study, jointly with the Pg external group. $\mathrm{Mj}$ and $\mathrm{Ma}$ were found to be phylogenetically closer, constituting sister branches.

The greater phylogenetic proximity between $\mathrm{Mj}$ and $\mathrm{Ma}$, and their distance from $\mathrm{Mb}$, based on the data obtained in the present study, can be explained by two important factors that must be discussed.

First, we may highlight the different habitat conditions in which these species are found. As already mentioned, individuals of the Mb species were collected from the Talhadinho Stream, whereas the other two species, $\mathrm{Mj}$ and Ma, were gathered from the Barra Mansa Dam. The fact 
that gene flow must be more intense in a stream environment in comparison to a dam, which supposedly is more isolated from other geographical areas, may explain the greater differentiation of $\mathrm{Mb}$ in relation to the other species. It is known that such isolation leads to inbreeding and loss of genetic variability in populations and species due to genetic drift (Shikano et al., 2010).

Another important factor is the introduction of $\mathrm{Mj}$ and $\mathrm{Ma}$ into hydrographic basins in the Brazilian State of São Paulo. Machado (1966) and Torloni et al. (1993) confirmed that between 1966 and 1973, M. jelskii and M. amazonicum were introduced into a CESP (Companhia Energética de São Paulo) aquaculture breeding station as part of the process to cultivate the fish Plagioscion squamosissimus, which originated from reservoirs in northeastern Brazil. Around 1970, probably by accident, these species reached the natural environment, initially in the Pardo River, next arriving in the Grande River and the reservoirs of Jupiá and Ilha Solteira, in the upper Paraná River. Another possibility posited by these authors is the recreational practice of "fish-pay", which utilizes these shrimp as live bait, and in many cases results in the release of unused specimens into the environment. Furthermore, larval, juvenile or other immature forms of these decapods can be transported inadvertently, associated with the roots of aquatic plants utilized to house and protect fishes in the reservoirs.

According to Magalhães et al. (2005), the hydrographic basins in the State of São Paulo have suffered severe anthropogenic interventions that have drastically modified the aquatic biota. The introduction of alien species into a particular environment can alter its genetic structure. The founder effect is a "bottleneck" phenomenon which, together with genetic drift, can diminish the available genetic variability. According to Bain (2006), the loss of genetic patrimony leads to hybridization in aquatic environments. As we mentioned previously, the high morphological similarity between $\mathrm{Mj}$ and Ma can indicate a probable mechanism of hybridization or formation of metapopulations (Taddei FG, personal communication).

According to Haag et al. (2006), the study of the genetic structure of metapopulations can offer important insights into the origin and destination of a species, and this study can be greatly influenced by three consequences of the founder effect: a) strong pressure from genetic drift during colonization; b) local inbreeding, which can result in hybridization and elevated rates of migration after subsequent immigration, and c) selection effects through the association of neutral genes with linked loci under selection.

In the present study, despite finding three specific RAPD-PCR markers capable of diagnosing $\mathrm{Mj}$ and $\mathrm{Ma}$, the analysis of the similarity indices and phylogenetic tree generated by the parsimony method showed high genetic similarity among them, consistent with the probable conditions of metapopulations or of interspecific hybrids. However, as there are no other researchs in the literature to corroborate these possibilities, other molecular studies and an analysis of individuals from other geographic areas are needed to resolve these doubts and to comprehend the relevant aspects of the founder event in the introduction of these species into our region.

The low level of genetic differentiation between $\mathrm{Mj}$ and $\mathrm{Ma}$ calls attention to the need for the creation of management policies that can minimize this problem and also prioritize the maintenance of endemic species. Several studies have demonstrated the importance of maintaining endemic or native species in the conservation and recovery of natural areas as constituting a fundamental aspect of preserving the biodiversity of ecosystems and improving our understanding of their biotic and abiotic interaction processes (Pérez et al., 2003; Facon et al., 2005; Magalhães et al., 2005; Roman, 2006; Heborg et al., 2007).

Nevertheless, despite the awareness of this problem, there are still no works in the 
literature that report on the environmental impacts, economic problems or even the possible alterations in the genetic structure of these organisms, in relation to their introduction into a different environment.

In this context, studies on genetic polymorphisms that determine the genetic structure of populations and species, utilized to better understand evolutionary, demographic or ecological factors, are very important to the conservation of these groups and constitute an essential field within the genetics of populations and conservation (Eizirik, 1996; Frankham, 2005).

We conclude that the present data obtained by the RAPD technique provide useful information on Macrobrachium species, thus enabling their genetic characterization and differentiation. These findings may be useful in further studies on these important crustacean species. This study must be complemented by other studies so that, over time, it will be possible to answer the questions related to the variability and differentiation among these species.

\section{ACKNOWLEDGMENTS}

Research supported by FAPESP and UNIRP (Centro Universitário de Rio Preto). We thank Dr. Claudia Márcia A. Carareto for analyzing the data using the PAUP 4.0 program.

\section{REFERENCES}

Bain MB (2006). Assessing impacts of introduced aquatic species: Grass carp in large systems. Environ. Manage. 17: 211-224.

Camargo OA Jr, Souza EA, Mendes-Costa MC, Santos JB, et al. (2007). Identification of Glomerella cingulata f. sp phaseoli recombinants by RAPD markers. Genet. Mol. Res. 6: 607-615.

Castiglioni L and de Campos Bicudo HE (2005). Molecular characterization and relatedness of Haematobia irritans (horn fly) populations, by RAPD-PCR. Genetica 124: 11-21.

Castro JP and Madi-Ravazzi L (2000). RAPD as genetic marker in taxonomic and evolutionary studies in the Drosophila buzzatii cluster. Drosophila Inf. Serv. 83: 26-32.

Cesniene T, Kleizaite V, Ursache R, Zvingila D, et al. (2010). Soil-surface genotoxicity of military and urban territories in Lithuania, as revealed by Tradescantia bioassays. Mutat. Res. 697: 10-18.

Cognato AI, Rogers SO and Teale SA (1995). Species diagnosis and phylogeny of the Ipis grandicollis group using random amplified polymorphic DNA. Ann. Entomol. Soc. Am. 88: 397-405.

Dellaporta SL, Wood J and Hicks J (1983). A plant DNA minipreparation: Version II. Plant Mol. Biol. Rep. 1: 19-21.

Eizirik E (1996). Ecologia molecular, genética da conservação e o conceito de unidades evolutivamente significativas. Rev. Bras. Genet. 19 (Suppl): 23-29.

Facon B, Jarne P, Pointier JP and David P (2005). Hybridization and invasiveness in the freshwater snail Melanoides tuberculata: hybrid vigour is more important than increase in genetic variance. J. Evol. Biol. 18: 524-535.

Frankham R (2005). Stress and adaptation in conservation genetics. J. Evol. Biol. 18: 750-755.

Garcia AL, Carrasco HJ, Schofield CJ, Stothard JR, et al. (1998). Random amplification of polymorphic DNA as a tool for taxonomic studies of triatomine bugs (Hemiptera: Reduviidae). J. Med. Entomol. 35: 38-45.

Guerra JC Jr, Issa MR, Carneiro FE, Strapazzon R, et al. (2010). RAPD identification of Varroa destructor genotypes in Brazil and other regions of the Americas. Genet. Mol. Res. 9: 303-308.

Haag CR, Riek M, Hottinger JW, Pajunen VI, et al. (2006). Founder events as determinants of within-island and amongisland genetic structure of Daphnia metapopulations. Heredity 96: 150-158.

Heborg LM, Weetman D, Oosterhout C and Hanfling B (2007). Genetic population structure and contemporary dispersal patterns of a recent European invader, the Chinese mitten crab, Eriocheir sinesis. Mol. Ecol. 16: 231-242.

Iqbal A, Khan AS, Khan IA, Awan FS, et al. (2007). Study of genetic divergence among wheat genotypes through random amplified polymorphic DNA. Genet. Mol. Res. 6: 476-481.

Kensley B and Walker I (1982). Palaemonid shrimps from the Amazon Basin, Brazil (Crustacea: Decapoda: Natantia). Smithsonian Contrib. Zool. 362: 1-28. 
Machado CEM (1966). Estações experimentais de biologia e psicultura em represas da CESP. Tech. Rep. 1: 1-12.

Maciel CR and Valenti WC (2009). Biology, fisheries and aquaculture of the Amazon River Prawn Macrobrachium amazonicum: a review. Nauplius 17: 61-79.

Magalhães C (2000). Abbreviated larval development of Macrobrachium jelskii (Crustacea: Decapoda: Palaemonidae) from the Rio Solimões floodplain, Brazil, reared in the laboratory. Nauplius 8: 1-15.

Magalhães C, Bueno S, Bond G, Valenti WC, et al. (2005). Exotic species of freshwater decapod crustaceans in State of São Paulo, Brazil: records and causes of their introduction. Biod. Conserv. 14: 1929-1945.

Magnusson WE, Vieira E and Lima AP (1987). Diets of Amazonian crocodilians. J. Heredity 21: 85-95.

Martin JW and Davis GE (2001). An updated classification of the recent crustacea. Nat. Hist. Mus. 39: 1-124.

Melo GAS (2003). Manual de Identificação dos Crustacea Decapoda de Água Doce do Brasil. Edições Loyola, Museu de Zoologia, São Paulo.

Moraes-Valenti PMC and Valenti WC (2007). Effect of intensification on grow-out of the Amazon River prawn Macrobrachium amazonicum. J. World Aquacult. Soc. 38: 516-526.

Moraes-Valenti P and Valenti WC (2010). Culture of the Amazon River Prawn Macrobrachium amazonicum. In: Freshwater Prawns: Biology and Farming (New MB, Valenti WC, Tidwell JH, D’Abramo LR, et al., eds.). Oxford, Wiley-Blackwell, 485-501.

Nath G, Maurya P and Gulati AK (2010). ERIC PCR and RAPD based fingerprinting of Salmonella typhi strains isolated over a period of two decades. Infect. Genet. Evol. 10: 530-536.

Nei M and Li WH (1979). Mathematical model for studying genetic variation in terms of restriction endonucleases. Proc. Natl. Acad. Sci. U. S. A. 76: 5269-5273.

Pérez JE, Salazar SK, Alfonsi C and Ruiz L (2003). Ictiofauna del Río Manzanares: A cuatro décadas de la introducción de Oreochromis mossambicus. Bol. Inst. Oceanogr. Venez. 42: 29-35.

Rahman SMZ, Khan MR, Islam S and Alam S (2009). Genetic variation of wild and hatchery populations of the catla Indian major carp (Catla catla Hamilton 1822: Cypriniformes, Cyprinidae) revealed by RAPD markers. Genet. Mol. Biol. 32: 197-201.

Rampelotti FT, Ferreira A, Tcacenco FA, Martins JF, et al. (2008). Genetic diversity of Tibraca limbativentris Stal (Hemiptera: Pentatomidae) of Santa Catarina and Rio Grande do Sul, Brazil, using RAPD. Neotrop. Entomol. 37: 20-29.

Roman J (2006). Diluting the founder effect: cryptic invasions expand a marine invader's range. Proc. Biol. Sci. 273: 2453-2459.

Roratto PA, Buchmann D, Santos S and Bartholomei-Santos ML (2008). PCR-mediated recombination in development of microsatellite markers: mechanism and implications. Genet. Mol. Biol. 31: 58-63.

Sampaio CM, Silva RR, Santos JA and Sales SP (2007). Reproductive cycle of Macrobrachium amazonicum females (Crustacea, Palaemonidae). Braz. J. Biol. 67: 551-559.

Shikano T, Shimada Y, Herczeg G and Merila J (2010). History vs. habitat type: explaining the genetic structure of European nine-spined stickleback (Pungitius pungitius) populations. Mol. Ecol. 19: 1147-1161.

Swofford DL (2000). PAUP 4.0. Phylogenetics Analysis Using Parsimony. Version 4. Sinauer Associates, Sunderland.

Taddei FG, Fransozo A, Costa RC, Cobo VJ, et al. (2006). Biologia Populacional e Crescimento dos Camarões Palemonídeos Macrobrachium jelskii (Miers, 1877) e Macrobrachium brasiliense (Heller, 1868) (Crustacea: Caridea) na Região Noroeste do Estado de São Paulo. Tese (Doutorado em Biológicas), Instituto de Biociências, Botucatu.

Torloni CEC, Corrêa ARA, Carvalho-Junior AA and Santos JJ (1993). Produção Pesqueira e Composição das Capturas em Reservatórios Sob Concessão da CESP nos Rios Tietê, Paraná e Grande no Período de 1986 a 1991. Série Produção Pesqueira, São Paulo, 1-73.

Valenti WC (1993). Freshwater prawn culture in Brazil. World Aquacult. 24: 30-34.

Wilkerson RC, Gaffigan TV and Bento LJ (1995). Identification of species related to Anopheles (Nyssorhynchus) albitarsis by random amplified polymorphic DNA-polymerase chain reaction (Diptera: Culicidae). Mem. Inst. Oswaldo Cruz 90: 721-732.

Williams JG, Kubelik AR, Livak KJ, Rafalski JA, et al. (1990). DNA polymorphisms amplified by arbitrary primers are useful as genetic markers. Nucleic Acids Res. 18: 6531-6535. 